\title{
Recovery of genetic diversity levels of a Neotropical tree in Atlantic Forest restoration plantations
}

\author{
Patricia Sanae Sujii ${ }^{a}$, Kaiser Dias Schwarcz ${ }^{\mathrm{a}}$, Carolina Grando ${ }^{\mathrm{a}}$, Ellida de Aguiar Silvestre ${ }^{\mathrm{a}}$, \\ Gustavo Maruyama Mori ${ }^{\mathrm{b}, \mathrm{c}}$, Pedro H.S. Brancalion ${ }^{\mathrm{d}}$, Maria Imaculada Zucchi ${ }^{\mathrm{b}}$,

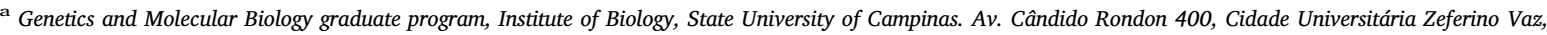 \\ 13083-875 Campinas, SP, Brazil \\ b Agência Paulista de Tecnologia dos Agronegócios, Rodovia SP 127, km 30, 13400-970 Piracicaba, SP, Brazil \\ c São Paulo State University (Unesp), Institute of Biosciences. Praça Infante Dom Henrique s/n. Pq Bitaru, CP 73601, 11330-900 São Vicente, SP, Brazil \\ ' Department of Forest Sciences, "Luiz de Queiroz" College of Agriculture, University of São Paulo, Av. Pádua Dias, 11, 13400-970 Piracicaba, SP, Brazil
}

A R T I C L E I N F O

\section{Keywords:}

Population genetics

Centrolobium tomenstosum

Atlantic Forest

Inbreeding

Effective population size

\begin{abstract}
A B S T R A C T
To support the long-term ecological viability of restoration projects, it is necessary to reach adequate levels of genetic diversity in spontaneously recolonizing and reintroduced populations. The importance of genetic diversity in the long-term viability of populations is acknowledged, but still poorly monitored in restoration projects. This study aimed to estimate the genetic diversity and inbreeding levels of populations of a tree species widely used in restoration projects in the Atlantic Forest of Brazil, Centrolobium tomentosum, exploring the potential of active restoration in successfully reestablishing populations with higher chances of long-term perpetuation in agricultural landscapes. We used both nuclear and chloroplast microsatellite markers to assess genetic parameters in juveniles and adult individuals in two high-diversity restoration plantations (28 and 60 years old), one disturbed fragment, and one large and well conserved protected area. We observed similar levels of genetic diversity and inbreeding, for juveniles and adults, in both restored and natural populations. Surprisingly, haplotype diversity was higher in restoration sites. We also found private alleles in juveniles in both restoration areas, and this is evidence of gene flow between restored and neighboring natural populations. However, we observed negative effects of inbreeding on the effective population size of populations from the disturbed natural remnant and restoration areas. These results provide evidence of the capacity of restoration plantations for recovering high levels of genetic diversity and the importance of maintaining large and wellconserved forest remnants to be used as seed sources for restoration efforts.
\end{abstract}

\section{Introduction}

Many international restoration initiatives have been launched to mitigate negative consequences of deforestation, habitat fragmentation, and other anthropogenic impacts on biodiversity and human wellbeing (Chazdon et al., 2015). These programs aim to restore millions of hectares of forest ecosystems and landscapes over the next decades and reestablish new populations of native tree species where they were locally extinct (Holl, 2017). The massive financial investments and political commitments to support restoration programs highlight the need for reliable monitoring approaches to safeguard key ecological principles for sustaining restoration success (Suding et al., 2015).

Biodiversity monitoring in restoration projects has been mostly focused on plant taxonomic diversity (Ruiz-Jaen and Mitchell Aide, 2005; Wortley et al., 2013) and functional diversity (Brancalion and
Holl, 2016), with few studies on phylogenetic (Schweizer et al., 2015) or genetic diversity (Rodrigues, 2013; Neto et al., 2014). Consequently, little is known about the potential of restoration interventions to reestablish similar genetic diversity levels compared to reference ecosystems. Although some conceptual frameworks have been recently proposed to monitor genetic issues in restoration projects (Thomas et al., 2014; Mijangos et al., 2015), on-the-ground assessments are scarce (but see Salas-Leiva et al., 2009; Neto et al., 2014).

The inbreeding level is another important genetic parameter for monitoring reintroduced populations in restoration programs, since the mating of closely related individuals may lead to a reduction in fitnessrelated traits such as survival and fertility, a phenomenon called inbreeding depression (Charlesworth and Willis, 2009). Inbreeding depression in plants, which is more common in trees than in annual herbs (Angeloni et al., 2011), may lead to reduced tree population

\footnotetext{
* Corresponding author

E-mail address: mizucchi@apta.sp.gov.br (M.I. Zucchi).
} 
viability in forest restoration areas. This issue may play an even more relevant role in restoration plantations in the tropics because most tree species are pollinated by animals (Bawa, 1990), and their maximum flight distances are not considered when distributing seedlings in the field. Therefore, it would be grounds for concern if inbreeding coefficients in the tree populations of restoration areas are higher than their normal levels found in natural, conserved populations, as observed in populations of Avicennia germinans (Salas-Leiva et al., 2009), and Inga vera (Neto et al., 2014).

Another threat to natural populations is the loss of diversity by genetic drift, which is stronger in small and isolated populations (Ellstrand and Elam, 1993; Frankham et al., 2014), like those typically found in restoration projects. If restoration initiatives are implemented to increase gene flow among fragments, this threat may be reduced. For example, a study of populations in second-growth forests indicated reduced genetic diversity in founding tree populations, reflecting a strong founder effect, and a shift towards genetically rich populations in the mid and long term due to gene flow at the landscape level (Sezen et al., 2007). Complementary, a study with the Neotropical tree Inga vera found reduced genetic diversity in adult individuals in restoration sites, but higher diversity in seedlings, probably due to gene flow from natural remnants to the sites ongoing restoration (Neto et al., 2014).

The use of genetics as a source of information to support decisionmaking in restoration programs is particularly important in developing tropical countries, where most of the global biodiversity hotspots are located (Myers et al., 2000). The restoration programs envisaged for tropical regions include the ambitious goal of restoring 20 million hectares of forest ecosystem and landscapes in Latin America and the Caribbean by 2020 (WRI, 2016) and restoring 15 million hectares of Brazil's Atlantic Forest by 2050 (Melo et al., 2013). The Aichi target 15 of the Convention on Biological Diversity, in particular, would require genetics to monitor its achievements, since restoration programs linked to this target are expected to contribute to conserving biodiversity at all hierarchical levels, from ecosystem to genes (Janishevski et al., 2015).

Although genetic studies on tropical trees in restoration projects may provide a necessary knowledge platform to plan, implement, and monitor restoration programs, few restoration genetics studies have been carried in tropical regions. Also, genetic concerns started to be considered just a few decades ago (Thomas et al., 2014; Mijangos et al., 2015).

In this study, we estimated the genetic diversity and inbreeding levels of populations of Centrolobium tomentosum, a tree species widely used in restoration projects in the Atlantic Forest of Brazil. Our aim was to address the potential of active restoration in successfully reestablishing populations with higher chances of long-term perpetuation in agricultural landscapes. To achieve this goal, we tested the following hypotheses: (i) even restoration areas with high species diversity were implanted in the past with low genetic diversity; (ii) populations from restoration areas have lower levels of genetic diversity than observed in natural remnants; (iii) populations from restoration areas have higher levels of inbreeding than those from natural remnants; (iv) there is no gene flow between restoration areas and neighboring areas as a consequence of their isolation in highly fragmented landscapes.

\section{Material and methods}

\subsection{Study species}

We selected Centrolobium tomentosum Guill. ex Benth (Fabaceae) as the model for this study, because this is a species widely used in the Atlantic Forest's restoration, and it is self-compatible (Aidar, 1992), which may lead to high levels of inbreeding in the absence of a pollinator. Therefore, this is a suitable model for assessing the limitation and the potential of restoration to recover adequate levels of genetic diversity and gene flow to sustain population persistence in restoration sites. Given these natural limitations on the recovery of genetic diversity and breeding rates in restoration projects, positive results with this species may indicate that sufficient genetic conservation may have been achieved in other tree species used in restoration.

C. tomentosum is a typical gap, intermediate succession species, with relatively fast growth and symbiotic associations with nitrogen-fixing microorganisms (Carvalho, 2005; Pagano, 2008). The main pollinators are large bees with long-distance flight capacity (genus Xylocopa, Bombus, Centris, and Megachile) (Aidar, 1992), which are one of the most common groups of pollinators of tropical canopy tree species (Bawa, 1990). Fruits are large samaras (approximately $9 \mathrm{~g}$ each) dispersed by wind, but most fruits fall under the canopy of the mother tree (Aidar and Joly, 2003). Although this species is self-compatible, most seeds that germinate are the result of outcrossing (Sujii et al., 2017).

\subsection{Study sites and sampling}

We selected four sample sites, all located within the seasonal semideciduous forest domain of the Brazilian Atlantic Forest of São Paulo state, southeastern Brazil, a global hotspot for biodiversity conservation (Myers et al., 2000). This is one of the most threatened vegetation types of the Atlantic Forest, with only $7.5 \%$ of its natural cover remaining (Ribeiro et al., 2009). All sites had a Cwa Köppen climate and were embedded in human-modified landscapes, dominated by sugarcane plantations, pastures, or urban areas.

We evaluated populations from two restoration sites (Rest). The first restoration area (Rest1) is a 15-ha plantation established from 1955 to 1960 along the riparian buffer of the Jaguari River, on a sugarcane farm in Cosmópolis municipality. The restoration model used was the random distribution of a high diversity of trees (71 species; $70 \%$ native), regardless of their successional performance, at a density of 833 individuals per hectare (Nogueira, 1977; Schweizer et al., 2015). The second restoration area (Rest2) is a 21-ha, high-diversity (141 species; 77\% native) plantation established from 1988 to 1990 onto the borders of Iracemápolis municipality's water-supply reservoir (Brancalion et al., 2014). Restoration was based on the combination of tree species of different successional stages in planting modules (6 pioneers and 2 early secondary, 1 late secondary or climax). Seedlings of Rest1 were mostly produced with seeds harvested in a 1901 reforestation site in Piracicaba, approximately $100 \mathrm{~km}$ away from Rest1, while seedlings used to establish Rest2 were obtained from two commercial forest nurseries of the region, but seed origin is unknown (Rodrigues et al., 1992).

We selected two natural remnants to compare with the forest restoration sites. The first natural remnant (Ref) was the Caetetus Ecological Station, the largest (2170 ha) and best conserved forest patch in the region (Durigan et al., 2000), chosen as the reference ecosystem for this study. The second natural remnant (Frag) was the Municipal reserve of Santa Genebra Forest, the largest urban semideciduous seasonal forest fragment in São Paulo State (252 ha), which was historically submitted to human-mediated disturbances typical of the study region: selective logging, fires, and edge effects, which have collectively led to the proliferation of ruderal climbers (Farah et al., 2014).

We sampled a total of 343 individuals (140 adult and 187 juvenile). From each restoration area, we sampled all adult individuals found in the site (large-sized trees found in the planting lines) and at least 30 juveniles. From each natural remnant, we sampled at least 30 adults and 30 juveniles (Table 1). Up to two juvenile individuals were sampled close to each adult individual, to avoid sampling a large proportion of siblings. From each individual, we collected plant tissue (leaf or vascular cambium) for DNA extraction (Cavallari et al., 2014), and obtained the coordinates with a GPS (GPSMAP62, Garmin). 
Table 1

Description of study areas and sample sizes.

\begin{tabular}{|c|c|c|c|c|c|}
\hline Study area & Fragment group & Area (ha) & Sample sizes & Coordinates & Other information \\
\hline Ref & Natural preserved & 2170 & $\begin{array}{l}46 \text { adult } \\
50 \text { juvenile }\end{array}$ & $\begin{array}{l}\text { W } 49^{\circ} 42^{\prime} 05^{\prime \prime} \\
\text { S } 22^{\circ} 24^{\prime} 11^{\prime \prime}\end{array}$ & $\begin{array}{l}\text { Preserved since the beginning of farming in the region and protected as an Ecological Station since } \\
1987 \text { (SMA, 1998) }\end{array}$ \\
\hline Frag & Natural disturbed & 252 & $\begin{array}{l}32 \text { adult } \\
33 \text { juvenile }\end{array}$ & $\begin{array}{l}\text { W } 47^{\circ} 06^{\prime} 40^{\prime \prime} \\
\text { S } 22^{\circ} 49^{\prime} 20^{\prime \prime}\end{array}$ & $\begin{array}{l}\text { Preserved since the beginning of farming in the region and protected since 1981, with recent drastic } \\
\text { changes in community structure (Farah et al., 2014) }\end{array}$ \\
\hline Rest1 & Restoration & 15 & $\begin{array}{l}19 \text { adult } \\
47 \text { juvenile }\end{array}$ & $\begin{array}{l}\text { W } 47^{\circ} 12^{\prime} 20^{\prime \prime} \\
\text { S } 22^{\circ} 40^{\prime} 18^{\prime \prime}\end{array}$ & Restored with 71 tree species, $70 \%$ native (Nogueira, 1977) \\
\hline Rest2 & Restoration & 21 & $\begin{array}{l}52 \text { adult } \\
64 \text { juvenile }\end{array}$ & $\begin{array}{l}\text { W } 47^{\circ} 31^{\prime} 09^{\prime \prime} \\
\text { S } 22^{\circ} 34^{\prime} 36^{\prime \prime}\end{array}$ & Restored with 141 tree species, $77 \%$ native (Rodrigues et al., 1992) \\
\hline
\end{tabular}

\subsection{Genotyping}

We amplified fragments of DNA from all individuals using seven nuclear microsatellites (nSSR) developed for the species: Ct01, Ct02, Ct03, Ct04, Ct05, Ct07 and Ct08 (Sujii et al., 2015). We also used five universal chloroplast microsatellites (cPSSR): ccmp02, ccmp03, ccmp04, ccmp07, and ccmp10 (Weising and Gardner, 1999). The nuclear loci analyzed were in linkage equilibrium and were considered as independent loci. The chloroplast genotypes were organized in haplotypes.

Genotypes were obtained using the Li-Cor 4300 DNA Analyzer (LiCor Biosciences, Lincoln, NE, USA) and we determined allele lengths using the 50-350 bp IRDye700 and 800 (Li-Cor) sizing standard and the Saga v.3.3 software (Li-Cor).

\subsection{Genetic analyses}

Microsatellite loci are usually neutral loci, but may be linked to some locus under natural selection. We tested if any of the loci showed any indication of selection, using LOSITAN (Antao et al., 2008). We ran this software using parameter settings of 50,000 simulations, confidence interval of 0.95 false discovery rate set to 0.1 , subsample size of 20, simulated FST of 0.05 and an attempted FST of 0.07 . We also employed a Bayesian framework to test for microsatellite neutrality using Bayescan 2.1 (Foll and Gaggiotti, 2008) with a burn-in period of 50,000 iterations, a sample size of 5000 , a thinning interval of 10 and 50 pilot runs, considering a false discovery rate of 0.10 .

In addition to natural selection, microsatellites analyses are subject to technical artifacts that may bias population genetics parameter estimates. To detect the presence of null alleles, large allele dropout and stuttering, we used Micro-checker 2.2.3 (Oosterhout et al., 2004) with a confidence interval of $99 \%$. Since this method assumes HardyWeinberg equilibrium, we also used the approach implemented in INEST 2.1 to simultaneously estimate null alleles frequency and inbreeding coefficient.

To estimate the nuclear genetic diversity for adults and juveniles separately and for all individuals in the population, we used expected heterozygosity under Hardy-Weinberg Equilibrium $\left(H_{E}\right)$, observed heterozygosity $\left(H_{O}\right)$, and allelic richness $(A r)$. We also compared Wright's fixation index $(f)$, as inbreeding estimator (Weir \& Cockerham, 1984), in different life stages and populations, estimated from nuclear genotypes for adults, juveniles, and populations. These parameters were estimated using diversity (Keenan et al., 2013) and PopGenKit (Paquette, 2012) packages from R (R Core Team, 2015). Confidence intervals were obtained with 1000 bootstrap replicates.

We estimated the variance in effective population size $\left(N_{e}\right)$ of adult and juvenile individuals based on Cockerham (1969), accounting for the sample size $(N)$, coancestry $(\Theta)$ and inbreeding, inferred from the fixation index $(f)$. The coancestry was inferred from the kinship coefficient using the estimator of J. Nasson (Loiselle et al., 1995), using the SPAGeDi 1.2 program (Hardy and Vekemans, 2002). The confidence intervals were obtained with 1000 bootstrap replicates, resampling loci. We also estimated the genetic representativeness $\left(N_{e} /\right.$ $N$ ) of each sample.

We assessed the number and frequency of private alleles in nuclear genotypes $(p A)$ and the private allelic richness $(p A r)$ in different life stages to look for indications of gene flow, using the ADZE software (Szpiech et al., 2008). Private allelic richness provides a measure of the singularity of each sample (Rodrigáñez et al., 2008).

\section{Results}

All nuclear loci used in this study were identified as neutral. We observed evidences of null alleles and stuttering in four out of seven loci, but their presence was not consistently detected within each sampling locality nor considering each group (adults and juveniles within each locality). Additionally, the inbreeding coefficient estimates explicitly considering null alleles did not differ substantially from the estimated values disregarding this methodological artifact. Therefore, we used the original dataset for further analyses.

The chloroplast haplotype diversity was higher in restoration areas than in natural remnants (Fig. 1). In natural remnant populations, we observed three (Ref) or four (Frag) haplotypes, both in adult and juvenile samples, while in restored populations, we observed six (Rest1) or 13 haplotypes (Rest2). The Shannon diversity index was higher in samples from restoration areas than that of natural remnants (Fig. 1). One haplotype was exclusive from juvenile samples (H11). The number of haplotypes observed in juvenile samples was always equal to or lower than that observed in adult samples, in spite of the larger sample size of juveniles.

The estimates of nuclear genetic diversity $\left(H_{O}\right.$ and $\left.A r\right)$ were similar

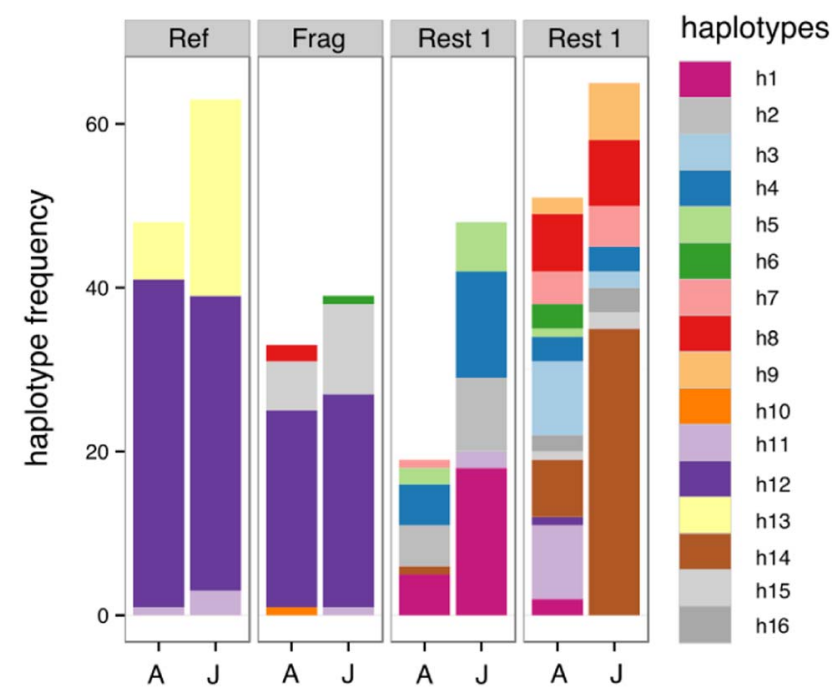

Fig. 1. Haplotype diversity in Centrolobium tomentosum populations from natural remnants (old-growth, reference forest - Ref; fragmented forest - Frag) and restoration areas (Rest1, Rest2) for adult (A) and juvenile (J) samples. Bars represent absolute frequency of each haplotype and the numbers above bars are Shannon's diversity index. 


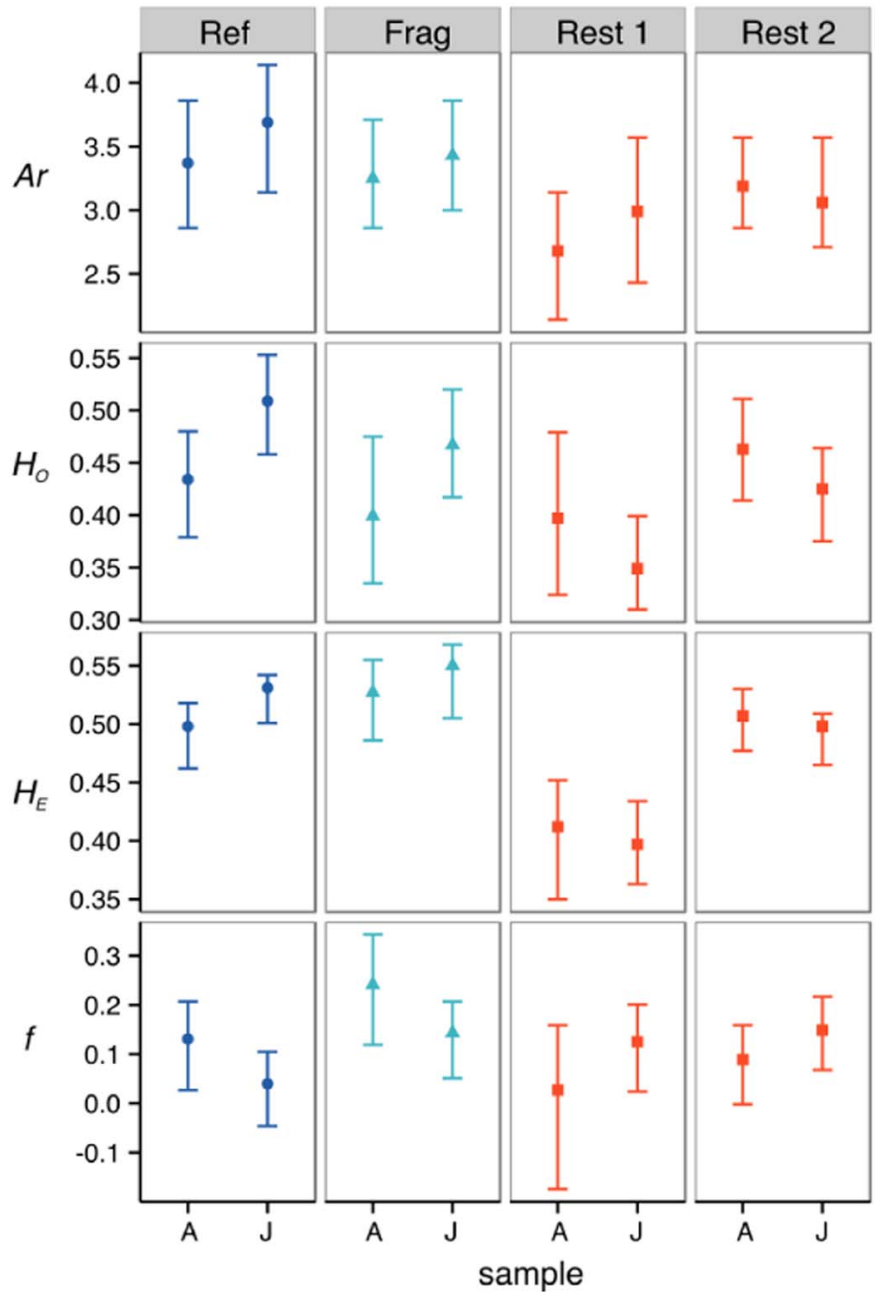

Fig. 2. Estimates of genetic diversity and inbreeding levels in $C$. tomentosum populations from natural remnants (old-growth, reference forest - Ref; fragmented forest - Frag) and restoration areas (Rest1, Rest2) for adult (A) and juvenile individuals (J). Ar: allelic richness; $H_{O}$ : observed heterozygosity; and $H_{E}$ : expected heterozygosity under HardyWeinberg equilibrium; $f$ : inbreeding coefficient. Bars indicate $95 \%$ confidence intervals.

in all samples from all populations (Fig. 2). Conversely, $H_{E}$ estimates for both adults and juveniles from Rest1 were lower than for the other populations. Inbreeding levels were similar among populations (Fig. 2). Comparing juvenile samples, only inbreeding level for Ref population was not consistently different from zero $\left(f=0.040, \quad \mathrm{CI}_{95 \%}\right.$ [-0.046-0.105]).

We observed private alleles from juvenile samples in both restoration areas. In Rest1, we observed nine private alleles (19\%) and in Rest2 we observed three (5\%). As we sampled all adult individuals found in these areas, the existence of private alleles indicated that new alleles were introduced in the restoration area by gene flow from surrounding areas. The private allelic richness of juvenile samples was higher than that of adult samples in restoration areas (Table 2).

The coancestry estimates were all very close to zero, indicating that

Table 2

Private allele $(p A)$ and private allelic richness $(p A r)$ in Centrolobium tomentosum populations from restoration areas (Rest).

\begin{tabular}{llll}
\hline \multirow{2}{*}{ Population } & $p A$ in juveniles & \multicolumn{2}{l}{$p A r$ (standard error) } \\
\cline { 3 - 4 } & & Adults & Juveniles \\
\hline Rest1 & $9(19 \%)$ & $0.014(0.016)$ & $0.224(0.136)$ \\
Rest2 & $3(5 \%)$ & $0.004(0.003)$ & $0.135(0.094)$ \\
\hline
\end{tabular}

Table 3

Estimates of fixation index $(f)$ with the confidence interval $\left(\mathrm{CI}_{95 \%}\right)$, coancestry $(\Theta)$, effective population size $\left(N_{e}\right)$, and genetic representativeness of each sample $\left(N_{e} / \mathrm{n}\right)$, and the sample size (n).

\begin{tabular}{|c|c|c|c|c|c|}
\hline Sample & $\mathrm{n}$ & $f\left(\mathrm{CI}_{95 \%}\right)$ & $\Theta$ & $N_{e}\left(\mathrm{CI}_{95 \%}\right)$ & $N_{e} / \mathrm{n}$ \\
\hline Ref - adults & 47 & $\begin{array}{l}0.131 \\
(0.027-0.207)\end{array}$ & 0 & $\begin{array}{l}45.90 \\
(54.74-32.27)\end{array}$ & 0.98 \\
\hline Ref - juvenile & 50 & $\begin{array}{l}0.040 \\
(-0.046-0.105)\end{array}$ & 0 & $\begin{array}{l}46.48 \\
(50.30-43.04)\end{array}$ & 0.93 \\
\hline Frag - adults & 32 & $\begin{array}{l}0.241 \\
(0.119-0.343)\end{array}$ & 0 & $\begin{array}{l}26.42 \\
(29.79-23.41)\end{array}$ & 0.83 \\
\hline Frag - juvenile & 33 & $\begin{array}{l}0.143 \\
(0.051-0.207)\end{array}$ & 0.00059 & $\begin{array}{l}29.70 \\
(32.54-27.12)\end{array}$ & 0.90 \\
\hline Rest1 - adults & 19 & $\begin{array}{l}0.027 \\
(-0.174-0.159)\end{array}$ & 0.00327 & $\begin{array}{l}16.11 \\
(18.71-13.84)\end{array}$ & 0.85 \\
\hline Rest1 - juvenile & 47 & $\begin{array}{l}0.125 \\
(0.024-0.201)\end{array}$ & 0.00014 & $\begin{array}{l}42.47 \\
(46.29-38.74)\end{array}$ & 0.90 \\
\hline Rest2 - adults & 42 & $\begin{array}{l}0.089 \\
(-0.002-0.159)\end{array}$ & 0.00062 & $\begin{array}{l}38.90 \\
(42.47-34.40)\end{array}$ & 0.93 \\
\hline Rest2 - juvenile & 57 & $\begin{array}{l}0.149 \\
(0.068-0.217)\end{array}$ & 0.00006 & $\begin{array}{l}49.04 \\
(54.63-44.11)\end{array}$ & 0.86 \\
\hline
\end{tabular}

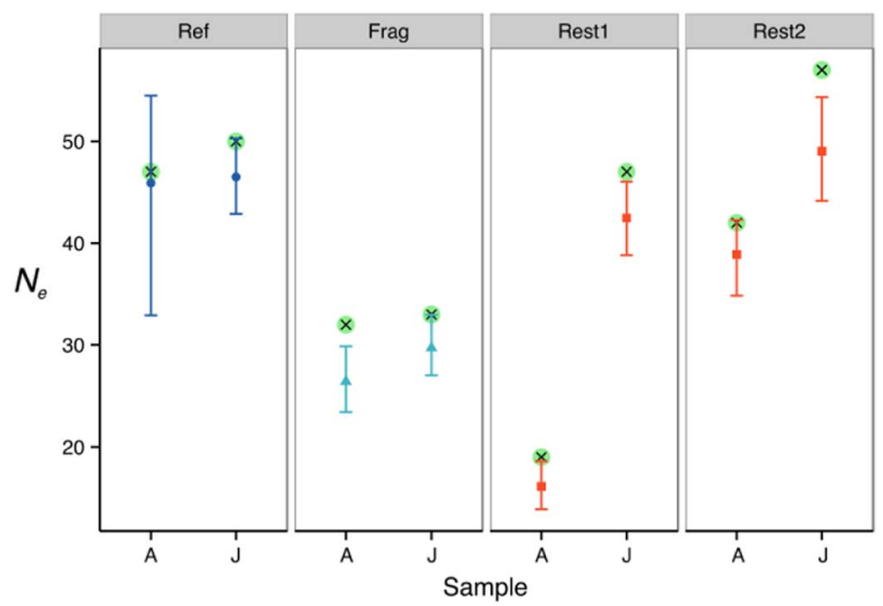

Fig. 3. Variance in effective population size (points, triangles and squares) of adult (A) and juvenile (J) samples of Centrolobium tomentosum from natural remnants (old-growth, reference forest - Ref; fragmented forest - Frag) and restoration areas (Rest1, Rest2). Error bars represent 95\% confidence intervals; and circles with crosses represent sample sizes.

samples were not related (Table 3). Adults and juveniles $N_{e}$ from the Ref area were not significantly different from sample size. All juvenile sample sizes from the Frag and Rest areas were significantly larger than $N_{e}$ (Fig. 3). The genetic representativeness was higher than $80 \%$ for all samples (Table 3).

\section{Discussion}

Overall, restored C. tomentosum populations had comparable levels of genetic diversity, haplotype diversity, coancestry and inbreeding to those found in forest remnants, indicating that both restoration areas were established with nursery-grown seedlings of high genetic diversity and produced with seeds from different sources.

\subsection{Restoration areas were implanted in the past with high genetic diversity}

Our results did not show evidence of drastic genetic diversity reductions, known as founder effect, in populations from restoration areas compared to natural remnants. The chloroplast DNA analysis of adult individuals showed the presence of six different haplotypes in Rest 1 , which indicates that seeds were sampled from, at least, six mother trees. In Rest2, the number of seed sources was even higher $(n=13)$. The haplotype diversity observed in restoration areas was 
higher than the diversity in populations from remnant forests, suggesting that the seeds used in restoration plantations were sampled from many seed-trees, probably from different forest fragments. The analysis of genetic diversity of nuclear DNA from adult samples did not show reduced allelic richness and heterozygosity, which are traditionally considered evidence of founder effect (Hartl and Clark, 2010).

This positive strategy for genetic conservation is aligned with the long history of scientific and practical maturation of ecological restoration in the Atlantic Forest, which now promotes the use of high levels of both species and genetic diversity in restoration plantations (Rodrigues et al., 2009; Brancalion et al., 2012). An additional factor that may have contributed to the high level of genetic and haplotype diversity found in this work is the large size of $C$. tomentosum seeds, because many mother trees have to be harvested in order to obtain a satisfactory amount of seeds compared to species bearing small- to medium-sized seeds.

Analyzing samples from restoration areas, we observed a lower Shannon diversity index in haplotypes of juvenile individuals than in adults. In contrast, this pattern was not observed in natural remnant populations. This may be a result of genetic drift effect, due to the small population size in restoration areas (Ellstrand and Elam, 1993). This may also be a consequence of outbreeding depression caused by the interaction of nuclear and cytoplasmic genomes (Scopece et al., 2010). If seeds used in the restoration project have very different provenances, mating among individuals from different origins may reduce seed or sampling viability (Scopece et al., 2010; Pinheiro et al., 2013). Thus, high levels of genetic diversity, especially when it is obtained from very distant populations, are not always beneficial to restoration success. Different studies have demonstrated the limitations of restoration and, in particular, active restoration to recover plant taxonomic diversity of tropical forests (Suganuma and Durigan, 2015; Shoo et al., 2016). Our case study indicates that it may not be the case for the genetic diversity of trees.

\subsection{Populations from restoration areas have similar levels of genetic diversity to those observed in natural remnants}

The evaluation of genetic diversity in this study was based on allelic richness, observed proportion of heterozygote genotypes, and allele frequencies of neutral regions of the genome. These estimates indicated that genetic diversity was similar between populations of restoration areas and natural remnants. Neutral genetic diversity has long been studied both in well preserved and in disturbed, fragmented populations, in order to assess the conservation status of targeted species (Lowe et al., 2005; Honnay and Jacquemyn, 2007; Aguilar et al., 2008; Pautasso, 2009; Vranckx et al., 2012; Lowe et al., 2015). Although high genetic diversity is not a guarantee of potential for adaptation, a significant correlation has already been detected between neutral levels of genetic diversity and population fitness (Reed and Frankham, 2003), thus allowing inferences on the potential of population persistence in restoration sites in relation to its levels of genetic diversity. In addition, high levels of genetic diversity have been particularly recommended for restoration of highly degraded sites and ecosystems, as a means of providing sufficient variation substrate for adaptation to contemporary adaptive filters, such as soil contamination, biological invasions, and climate change (Lesica and Allendorf, 1999).

The results of genetic diversity for juvenile samples indicated that there was no evidence of negative effects of restoration design on genetic diversity in the first few generations after implantation. Studies with Myroxylon peruiferum, Piptadenia gonoacantha, and Casearia sylvestris, tree species from the Atlantic Forest in the same study areas, also showed similar results (Zucchi et al., 2017). Studies with Hymenaea stigonocarpa and Dipteryx alata, tree species from Cerrado (Brazilian Savanna), also showed a larger number of alleles in restoration areas than in natural remnants, probably due to a mixture of seeds from different forest fragments to produce seedlings to be used in the restoration project (Rodrigues, 2013). Thus, although previous research has shown that the fragmentation of continuous forest patches into many small patches reduces the genetic diversity of trees (Honnay and Jacquemyn, 2007; Aguilar et al., 2008; Lowe et al., 2015), the recreation of small patches of forest through ecological restoration may re-establish similar or even higher levels of genetic diversity compared to both fragmented and conserved forest remnants. This positive result relies on the key role of seed collection for improving planting stocks in forest restoration, as already demonstrated for the same study region (Brancalion et al., 2012).

\subsection{Populations from restoration areas have similar levels of inbreeding to those from natural remnants}

Inbreeding levels of restored populations were not significantly different from that of natural populations. However, for juvenile individuals, only the well-preserved remnant had a sample with an inbreeding coefficient not significantly different from zero. Also, we observed high estimates of inbreeding levels in Frag. As C. tomentosum is an outcrossing species, inbreeding in Rest and Frag may be an indication of mating among relatives caused by deficit of pollination services. Although the reestablishment of pollination services in restoration areas is not well understood (but see Kaiser-Bunbury et al., 2017), it is known that specialized plant-pollinator interactions are more difficult to recover, and that highly fragmented landscapes may not adequately support pollinator movement to restored sites (Dixon, 2009). Thus, indications of pollination service deficits in restoration areas are a matter of concern and should be more thoroughly investigated. An alternative explanation for the higher inbreeding levels in non-reference sites is the small population size of other areas.

As expected, the $N_{e}$ and the sample size were similar in both samples from Ref, indicating that inbreeding and coancestry did not have a negative effect on genetic diversity in the studied populations. For most samples from Frag and Rest, the $N_{e}$ was significantly lower than the sample size. This is a potential effect of inbreeding or crossing among relatives, which may be due to the small population size, associated with spatial genetic structure and deficit of pollination service (Sujii et al., 2017). Genetic representativeness was high for all samples, which indicates maintenance of genetic diversity over the next generations (Vencovsky and Crossa, 2003; Raposo et al., 2007). However, the effective population sizes of adults were smaller, in both restoration areas, than that recommended for the short-term $(\mathrm{Ne} \geq 100)$ and longterm $(\mathrm{Ne} \geq 1000)$ conservation of populations (Frankham et al., 2014). This emphasizes the importance of enhancing connectivity with surrounding fragments.

\subsection{There is gene flow between restoration areas and neighboring areas}

We sampled all adult individuals in restoration areas, so if a haplotype is present exclusively in juveniles, it can indicate that the seeds dispersed from trees in neighboring areas or that the parental tree was already dead. One haplotype (H11) was present in juveniles and absent in adults in Rest 1 , and it was observed in only two juvenile individuals. This absence of evidence for gene flow by seed dispersal was expected for a species with a large samara and, thus, low seed dispersal capacity (Greene and Johnson, 1993; Sujii et al., 2017).

The presence of private alleles in juvenile samples of restoration areas is evidence of gene flow from neighboring areas. The $p A r$ estimates for juvenile samples from restoration areas were significantly higher than for adult samples. As we sampled all adult individuals from the restoration areas, private alleles in juveniles probably came from neighboring areas, most likely by pollen flow due to its seeds' low dispersal capabilities (Sujii et al. unpublished data). This evidence of gene flow between restoration areas and the surrounding natural remnants indicates that restoration populations can be a source of 
alleles for previously isolated fragments, contributing to the increase of the effective population size in the set of neighboring populations. This is still a poorly studied contribution of restoration to biodiversity conservation in human-modified landscapes. However, it may also be the source of a problem for native populations' conservation, since nonlocal alleles may cause outbreeding depression, i.e., a decline in progeny fitness by the crossing of individuals adapted to different conditions (Lesica and Allendorf, 1999).

\section{Conclusion}

Our results corroborate other studies that evidenced the potential of ecological restoration to recover genetic diversity (Smulders et al., 2008; Ritchie and Krauss, 2012). Our findings highlight the importance of using seed pools with high genetic diversity in restoration plantations to avoid strong founder effects. Thus, we suggest the use of seeds from different sources to produce seedlings for restoration areas, as well as large and well-conserved remnants as main sources of seeds, as they may have been subjected to reduced effects of inbreeding on effective population size. We also suggest seed collection from local provenances to prevent future outbreeding depression in restored sites.

We also observed the presence of gene flow from neighboring populations, which indicates that it is possible to recover pollination services in restoration plantations, even in highly fragmented landscapes. However, the lower $N_{e}$ in disturbed and restoration areas reinforces the importance of enhancing connectivity among fragments to create metapopulation dynamics, increasing the effective population size and slowing down genetic drift effects, key issues for supporting the ecological viability and persistence of restored populations in a changing environment.

\section{Author contribution}

KDS, PHSB and MIZ conceived and designed the research; PSS, KDS, CG and EAS performed the experiments; PSS analyzed the data and wrote the manuscript; PSS, KDS, CG, EAS, GMM, PHSB and MIZ discussed results and edited the manuscript.

\section{Acknowledgements}

We thank the Instituto Florestal, the José Pedro de Oliveira Foundation, the Brazilian National Council for Scientific and Technological Development (CNPq) and the Chico Mendes Institute for Biodiversity Conservation (ICMBio) for sampling and research permits. We are also grateful to José Baldin Pinheiro for the laboratory structure. The authors declare that they have no conflict of interest.

Funding: This work was supported by the São Paulo Research Foundation (FAPESP - 2011/50296-8; 2012/03246-8); the Higher Education Personnel Improvement Coordination (CAPES); and the National Council for Scientific and Technological Development (CNPq - 304817/2015-5).

\section{References}

Aguilar, R., Quesada, M., Ashworth, L., Herrerias-Diego, Y., Lobo, J., 2008. Genetic consequences of habitat fragmentation in plant populations: susceptible signals in plant traits and methodological approaches. Mol. Ecol. 17 (24), 5177-5188.

Aidar, M.P.M., 1992. Ecologia do araribá (Centrolobium tomentosum Guill. ex Benth Fabaceae) e o ecótono mata ciliar da bacia do rio Jacaré-Pepira, São Paulo. (MS Dissertation) Universidade Estadual de Campinas, Campinas.

Aidar, M.P.M., Joly, C.A., 2003. Dinâmica da produção e decomposição da serapilheira do araribá (Centrolobium tomentosum Guill. ex Benth. - Fabaceae) em uma mata ciliar, Rio Jacaré-Pepira, São Paulo. Rev. Bras. Bot. 26 (2), 193-202.

Angeloni, F., Ouborg, N.J., Leimu, R., 2011. Meta-analysis on the association of population size and life history with inbreeding depression in plants. Biol. Conserv. $144,35-43$.

Antao, T., Lopes, A., Lopes, R.J., Beja-Pereira, A., Luikart, G., 2008. LOSITAN: a

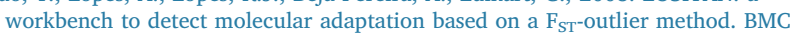
Bioinf. 9, 323.
Bawa, K.S., 1990. Plant-pollinator interactions in tropical rain forests. Annu. Rev. Ecol. Syst. 399-422.

Brancalion, P.H.S., Holl, K.D., 2016. Functional composition trajectory: a resolution to the debate between Suganuma, Durigan, and Reid. Restor. Ecol. 24, 1-3.

Brancalion, P.H.S., Viani, R.A.G., Aronson, J., et al., 2012. Improving planting stocks for the Brazilian Atlantic Forest restoration through community-based seed harvesting strategies. Restor. Ecol. 20, 704-711.

Brancalion, P.H., Cardozo, I.V., Camatta, A., et al., 2014. Cultural ecosystem services and popular perceptions of the benefits of an ecological restoration project in the Brazilian Atlantic Forest. Restor. Ecol. 22 (1), 65-71.

Carvalho, P.E.R., 2005. Araruva. In: Embrapa Circular Técnica, pp. 103 (Colombo).

Cavallari, M.M., Siqueira, M.V., Val, T.M., et al., 2014. A modified acidic approach for DNA extraction from plant species containing high levels of secondary metabolites. Genet. Mol. Res. 13 (3), 6497-6502.

Charlesworth, D., Willis, J.H., 2009. The genetics of inbreeding depression. Nat. Rev. Genet. 10 (11), 783-796.

Chazdon, R.L., Brancalion, P.H., Lamb, D., et al., 2015. A policy-driven knowledge agenda for global forest and landscape restoration. Conserv. Lett. http://dx.doi.org/10.1111/ conl.12220.

Cockerham, C.C., 1969. Variance of gene frequencies. Evolution 72-84.

Dixon, K.W., 2009. Pollination and restoration. Science 325 (5940), 571.

Durigan, G., Franco, G.A.D.C., Saito, M., et al., 2000. Estrutura e diversidade do componente arbóreo da floresta na Estação Ecológica dos Caetetus, Gália, SP. Rev. Bras. Bot. 23, 371-383.

Ellstrand, N.C., Elam, D.R., 1993. Population genetic consequences of small population size: implications for plant conservation. Annu. Rev. Ecol. Syst. 24, 217-242.

Farah, F.T., Rodrigues, R.R., Santos, F.A.M., et al., 2014. Forest destructuring as revealed by the temporal dynamics of fundamental species-case study of Santa Genebra Forest in Brazil. Ecol. Indic. 37, 40-44.

Foll, M., Gaggiotti, O., 2008. A genome-scan method to identify selected loci appropriate for both dominant and codominant markers: a Bayesian perspective. Genetics 180 (2), 977-993.

Frankham, R., Bradshaw, C.J., Brook, B.W., 2014. Genetics in conservation management: revised recommendations for the 50/500 rules, Red List criteria and population viability analyses. Biol. Conserv. 170, 56-63.

Greene, D.F., Johnson, E.A., 1993. Seed mass and dispersal capacity in wind-dispersed diaspores. Oikos 69-74.

Hardy, O.J., Vekemans, X., 2002. SPAGeDi: a versatile computer program to analyse spatial genetic structure at the individual or population levels. Mol. Ecol. Notes 2, 618-620.

Hartl, D.L., Clark, A.G., 2010. Princípios de genética de populações. Artmed, Porto Alegre, Rio Grande do Sul.

Holl, K.D., 2017. Restoring tropical forests from the bottom up. Science 394 (355), 455-456.

Honnay, O., Jacquemyn, H., 2007. Susceptibility of common and rare plant species to the genetic consequences of habitat fragmentation. Conserv. Biol. 21 (3), 823-831.

Janishevski, L., Santamaria, C., Gidda, S.B., et al., 2015. Ecosystem restoration, protected areas and biodiversity conservation. Unasylva 245, 19-28.

Kaiser-Bunbury, C.N., Mougal, J., Whittington, A.E., et al., 2017. Ecosystem restoration strengthens pollination network resilience and function. Nature 542 (7640), 223-227.

Keenan, K., McGinnity, P., Cross, T.F., et al., 2013. Diversity: an R package for the estimation of population genetics parameters and their associated errors. Methods Ecol. Evol. 4, 782-788.

Lesica, P., Allendorf, F.W., 1999. Ecological genetics and the restoration of plant communities: mix or match? Restor. Ecol. 7 (1), 42-50.

Loiselle, B.A., Sork, V.L., Nason, J., Graham, C., 1995. Spatial genetic structure of a tropical understory shrub, Psychotria officinalis (Rubiaceae). Am. J. Bot. 1420-1425.

Lowe, A.J., Boshier, D., Ward, M., Bacles, C.F., Navarro, C., 2005. Genetic resource impacts of habitat loss and degradation; reconciling empirical evidence and predicted theory for neotropical trees. Heredity 95 (4), 255-273.

Lowe, A.J., Cavers, S., Boshier, D., et al., 2015. The resilience of forest fragmentation genetics - no longer a paradox - we were just looking in the wrong place. Heredity 115 (2), 97-99.

Melo, F.P., Pinto, S.R., Brancalion, P.H., et al., 2013. Priority setting for scaling-up tropical forest restoration projects: early lessons from the Atlantic Forest Restoration Pact. Environ. Sci. Pol. 33, 395-404.

Mijangos, J.L., Pacioni, C., Spencer, P., Craig, M.D., 2015. Contribution of genetics to ecological restoration. Mol. Ecol. 24 (1), 22-37.

Myers, N., Mittermeier, R.A., Mittermeier, C.G., et al., 2000. Biodiversity hotspots for conservation priorities. Nature 403 (6772), 853-858.

Neto, O.C., Aguiar, A.V., Twyford, A.D., et al., 2014. Genetic and ecological outcomes of Inga vera Subspaffinis (Leguminosae) tree plantations in a fragmented tropical landscape. PLoS One 9, e99903.

Nogueira, J.C.B., 1977. Reflorestamento heterogêneo em essências indígenas. Instituto Florestal, São Paulo, São Paulo.

Oosterhout, V.C., Hutchinson, W.F., Wills, D.P.M., Shipley, P., 2004. PROGRAM NOTE MICRO-CHECKER: software for identifying and correcting genotyping errors in microsatellite. Mol. Ecol. Notes 4, 535-538.

Pagano, M.C., 2008. Rhizobia associated with neotropical tree Centrolobium tomentosum used in riparian restoration. Plant Soil Environ. 54, 498-508.

Paquette, S.R., 2012. PopGenKit: Useful Functions for (Batch) File Conversion and Data Resampling in Microsatellite Datasets. R package version 1.0. http://CRAN.R-project. org $/$ package $=$ PopGenKit.

Pautasso, M., 2009. Geographical genetics and the conservation of forest trees. Perspect. Plant Ecol. Evol. Syst. 11 (3), 157-189. 
Pinheiro, F., Cozzolino, S., Barros, F., Gouveia, T.M., et al., 2013. Phylogeographic structure and outbreeding depression reveal early stages of reproductive isolation in the Neotropical orchid Epidendrum denticulatum. Evolution 67 (7), 2024-2039.

R Core Team, 2015. R: a language and environment for statistical computing. R Foundation for Statistical Computing, Vienna, Austria (URL). http://www.R-project. org.

Raposo, A., Martins, K., Ciampi, A.Y., et al., 2007. Diversidade genética de populações de andiroba no Baixo Acre. Pesq. Agrop. Brasileira 42 (9), 1291-1298.

Reed, D.H., Frankham, R., 2003. Correlation between fitness and genetic diversity. Conserv. Biol. 17, 230-237.

Ribeiro, M.C., Metzger, J.P., Martensen, A.C., et al., 2009. The Brazilian Atlantic Forest: how much is left, and how is the remaining forest distributed? Implications for conservation. Biol. Conserv. 142 (6), 1141-1153.

Ritchie, A.L., Krauss, S.L., 2012. A genetic assessment of ecological restoration success in Banksia attenuata. Restor. Ecol. 20 (4), 441-449.

Rodrigáñez, J., Barragán, C., Alves, E., et al., 2008. Genetic diversity and allelic richness in Spanish wild and domestic pig population estimated from microsatellite markers. Span. J. Agric. Res. 6, 107-115.

Rodrigues, N.B., 2013. Variabilidade genética de populações de Hymenaea stigonocarpa Mart. ex Hayne e Dipteryx alata Vogel em áreas nativas e em plantios de recuperação de áreas degradadas em Paracatu, MG. MS Dissertation. Universidade de Brasília, Brasília.

Rodrigues, R.R., Leitão Filho, H.D.F., Crestana, M.S.M., 1992. Revegetação do entorno da represa de abastecimento de água do município de Iracemápolis, SP. In: Simpósio sobre recuperação de áreas degradadas - Anais, Curitiba, Paraná.

Rodrigues, R.R., Lima, R.A.F., Gandolfi, S., Nave, A.G., 2009. On the restoration of high diversity forests: 30 years of experiences in the Brazilian Atlantic Forest. Biol. Conserv. 142, 1242-1251.

Ruiz-Jaen, M.C., Mitchell Aide, T., 2005. Restoration success: how is it being measured? Restor. Ecol. 13 (3), 569-577.

Salas-Leiva, D.E., Mayor-Durán, V.M., Toro-Perea, N., 2009. Genetic diversity of black mangrove (Avicennia germinans) in natural and reforested areas of Salamanca Island Parkway, Colombian Caribbean. Hydrobiologia 620 (1), 17-24.

Schweizer, D., Machado, R., Durigan, G., Brancalion, P.H.S., 2015. Phylogenetic patterns of Atlantic forest restoration communities are mainly driven by stochastic, dispersal related factors. For. Ecol. Manag. 354, 300-308.

Scopece, G., Lexer, C., Widmer, A., Cozzolino, S., 2010. Polymorphism of postmating reproductive isolation within plant species. Taxon 59 (5), 1367-1374.

Secretaria do Meio Ambiente, 1998. Atlas das unidades de conservação ambiental do Estado de São Paulo. In: Parte II: Interior. Secretaria de Estado do Meio Ambiente. Metalivros, São Paulo.
Shoo, L.P., Freebody, K., Kanowski, J., Catterall, C.P., 2016. Slow recovery of tropical oldfield rainforest regrowth and the value and limitations of active restoration. Conserv. Biol. 30 (1), 121-132.

Smulders, M.J., Cottrell, J.E., Lefèvre, F., et al., 2008. Structure of the genetic diversity in black poplar (Populus nigra L.) populations across European river systems: consequences for conservation and restoration. For. Ecol. Manag. 255 (5), 1388-1399.

Suding, K., Higgs, E., Palmer, M., et al., 2015. Committing to ecological restoration. Science 8, 638-640.

Suganuma, M.S., Durigan, G., 2015. Indicators of restoration success in riparian tropical forests using multiple reference ecosystems. Restor. Ecol. 23 (3), 238-251.

Sujii, P.S., Schwarcz, K.D., Grando, C., et al., 2015. Isolation and characterisation of microsatellite markers for Centrolobium tomentosum (Fabaceae), a neotropical tree species widely used for Atlantic Rainforest restoration. Conserv. Genet. Resour. 7 (3), 733-734.

Sezen, U.U., Chazdon, R.L., Holsinger, K.E., 2007. Multigenerational genetic analysis of tropical secondary regeneration in a canopy palm. Ecology 88 (12), 3065-3075.

Sujii, et al., 2017. High gene flow through pollen partially compensate spatial limited seed dispersal in a Neotropical tree. in prep to Journal of Heredity (unpublished data).

Szpiech, Z.A., Jakobsson, M., Rosenberg, N.A., 2008. ADZE: a rarefaction approach for counting alleles private to combinations of populations. Bioinformatics 24 (21), 2498-2504.

Thomas, E., Jalonen, R., Loo, J., et al., 2014. Genetic considerations in ecosystem restoration using native tree species. For. Ecol. Manag. 333, 66-75.

Vencovsky, R., Crossa, J., 2003. Measurements of representativeness used in genetic resources conservation and plant breeding. Crop Sci. 43 (6), 1912-1921.

Vranckx, G.U., Jacquemyn, H., Muys, B., Honnay, O., 2012. Meta-analysis of susceptibility of woody plants to loss of genetic diversity through habitat fragmentation. Conserv. Biol. 26 (2), 228-237.

Weising, K., Gardner, R.C., 1999. A set of conserved PCR primers for the analysis of simple sequence repeat polymorphisms in chloroplast genomes of dicotyledonous angiosperms. Genome 42, 9-19.

Weir, B.S., Cockerham, C.C., 1984. Estimating F statistics for the analysis of population structure. Evolution 38 (6), 1358-1370.

Wortley, L., Hero, J.M., Howes, M., 2013. Evaluating ecological restoration success: a review of the literature. Restor. Ecol. 21 (5), 537-543.

WRI, 2016. World Resources Institute Initiative 20x20. Available at: www.wri.org/ourwork/project/initiative-20x20.

Zucchi, et al., 2017. Restoring genetic diversity in a threatened ecosystem. submitted to Restoration Ecology (unpublished data). 